\title{
History of The Establishment of 'Aisyiyah Bustanul Athfal Pre-School in 1919-2019 in West Papua
}

\author{
Fathurrahman $^{1}$, Hayudi ${ }^{2}$ \\ \{fathurphysics@gmail.com ${ }^{1}$ \} \\ Universitas Pendidikan Muhammadiyah Sorong, West Papua, Indonesia
}

\begin{abstract}
Abstrack. Awareness of young generation was the primary key of nation future development led to Aisyiyah organization to contribute to prepare the best young generation from the very beginning. Since Aisyiyah Bustanul Athfal Kindergarten was built in 1919 until now, there has not an authentic document which identified its establishment comprehensively. It was worrying because it could make us lost the identity and the foundation of it in treading challenges in the second century. Efforts to obtain Aisyiyah Bustanul Athfal Kindergarten establishment report were difficult to do. Thus, it needed to be supported with comprehensive research using sociology approach in order to the history and development of Aisyiyah Bustanul Athfal Kindergarten could be presented as a positive historical establishment for society.
\end{abstract}

Keywords: Kindergarten, foundation, sociology, development

\section{Introduction}

Awareness of young generation was the primary key of nation future development led to Aisyiyah organization to contribute to prepare the best young generation from the very beginning. 'Aisyiyah has given its contribution to the society starting from 19 May 1917 (www.aisyiyah.or.id), which meant that it had already served the society in a long time. It has seen that young generation especially kindergarten aged children as a great potential in the future. This awareness led 'Aisyiyah to establish kindergarten in 1919, which named Froebel Kindergarten 'Aisyiyah, the first kindergarten owned by the local people in the colonial era (Siti Dalilah Candrawati, Rubrik Opini Majalah Walida, AprilMei 2015).

One of the ways in facing $2^{\text {nd }}$ century challenge was reflecting every experience. Unfortunately, the report of ABA kindergarten (TK) mapping in West Papua has not been well documented that we could not trace its historical development well.

Since there was no written data about the development of TK ABA because of the missing information, there were many obstacles on the communication chain that run continuously.

This research tried to collecting, developing, confirming, synchronizing, and interpreting the related data to make it easier, cheaper, and affordable. Based on the explanation above, the researcher was interested in studying the historical development of 'Aisyiyah Bustanul Athfal kindergarten in West Papua. 


\section{Literature}

\subsection{The Nature of History}

Reviewing the nature of history, etymologically, historical terms derived from Arabic, namely "syajaratun" which meant "tree" or "origin" which then continuously developed and absorbed in Malay language "syajarah" which eventually became the word "sejarah" in Indonesian. Whereas history in English was came from Greek, namely "historia" which meant inquiry, interview, interrogation from an eyewitness and also reports on actions (Sjamsudin, 2012: 13). Several experts gave their opinion about the essence of history below:

a. Herodotus (484-425), stated that history was a study telling about ins and out of the rise and fall of a character, society or civilization (Hapsari, 2013: 7).

b. Muhammad Yamin defined history as a knowledge that was arranged based on investigation result of several events that could be proven (Tamburaka, 2012: 11).

Based on the statement above, history was a past event experienced by humans, that contained time and place. Thus, we could state that history was a knowledge that studied any important events in human life in the past.

\subsection{The Concept of History}

History as a knowledge was developed based on the concepts below, 2013: 38 et.seq): a. History as a realization which covered all events and changes happened in human life.

b. History as a recording. It was a disclosure and representation about a series of events and changes on the human life in a systematic time dimension.

In this research, the knowledge of history was used as the basis of understanding the development of researched kindergarten. It development then could be interpreted comprehensively.

\subsection{The Definition of Kindergarten}

Referring to the English term, Kindergarten is a term given by Frobel - a German education figure - for children's education outside the home. Kindergarten in Indonesia is known as "Taman Kanak-kanak".

According to Law Number 20 of 2003 concerning the National Education System Article 1 point 14 in the National Education Ministry (2010: 1) stated that early childhood education was a guiding effort shown to children from birth to six years old carried out by providing educational stimulus to help their development and growth both physically and spiritually so that children have readiness to enter further education.

It was in line with Suyadi (2010: 18) where kindergarten was interpreted as a form of Early Childhood Education Unit on the formal pathway held for children aged 4-6 years. Then, the criteria were divided into two groups, namely children aged 4-5 years enter group A (small) and ages 5-6 years enter group B (large).

Based on those opinions, it could be seen that kindergarten was an educational institution prepared specifically for children. The learning process carried out in kindergarten did not require good product or output academically, but rather pays attention to the child's process in passing through the stages of development. 


\subsection{Kinds of Kindergarten}

Adapted from NSPK (Norms, Standards, Procedures, and Criteria) concerning to the Implementation Guidelines for the Kindergarten Program issued by the Ministry of Education and Culture of the Republic of Indonesia in 2013, Kindergarten was divided into two, namely Public Kindergarten which was established by the government and was under the auspices of the government. The government intervention toward public kindergarten was very dominant in the implementation of its education system. The other type was Private Kindergarten, that was a kindergarten established by the community or a non-state foundation and the implementation of the education system was under the auspices of personal or community groups or related foundations.

\subsection{Principles for Organizing Kindergarten}

As explained in the Norms, Standards, Procedures and Criteria (NSPK) concerning the Implementation Guidelines for the Kindergarten Program issued by the Ministry of Education and Culture of the Republic of Indonesia in 2013, the following were the principles of the implementation of Kindergarten were:

a. Service availability, it was directed to support the success of the transition period to accommodate children from four to six years old so that all age groups received Early Childhood Education services.

b. Transisional, it was directed to support the success of the transition period to apply teaching approach in the initial class of kindergarten (TK) and elementary school (SD).

c. Cooperation. Cooperation should prioritize communication and cooperation with various institutions, society, and organization in order to be able to synchronize and guarantee the learning support in the transition period between initial class at kindergarten and elementary school.

d. Kinship. It was developed with the spirit of kinship and foster mutual attentiveness, care, and nurturing.

e. Sustainability. It was carried out sustainably by empowering various potency and support from any related parties.

f. Tiered guidance was carried out to ensure the existence and management of Kindergarten and Elementary School by supervisors, Education board of region and province, and Directorate of Early Childhood Education, Director General of Early Childhood Education, Non Formal and Informal.

\section{Research Method}

\subsection{Research Design}

This research was a historical study that used historical methods. Historical methods, according to Gottschalk (1983: 32), could be understood as a process for examining and analyzing the recordings and relics of the past critically, which were identical to historical sources. In this study, the researcher fully participated in the historical method which consisted of four main steps, namely: (1) heuristics or collection of historical sources containing historical data, (2) criticism or selection of historical sources, (3) interpretation of 
historical facts as a result of criticism procedures, and (4) historiography or writing of historical works.

The approach used in this research was sociology approach especially educational sociology. By this approach, historical events would be seen as a social phenomenon. In social phenomenon, interaction between society and stakeholder was very influence.

\subsection{Research Procedure}

The procedures of historical research was a set of rules and systematic principles to effectively collect historical sources, assess them critically and propose a synthesis of the results achieved in written form (Dudung Abdurrahman, 1999: 43-44). In the heuristic or collection of historical sources step, the author attempted to trace written sources (archives or documentary materials) and oral sources (informants). Tracking of written sources was centered on documentary material issued by the investigated board, in this case "Aisyiyah in West Papua.

Therefore, the research procedures would be applied as follow:
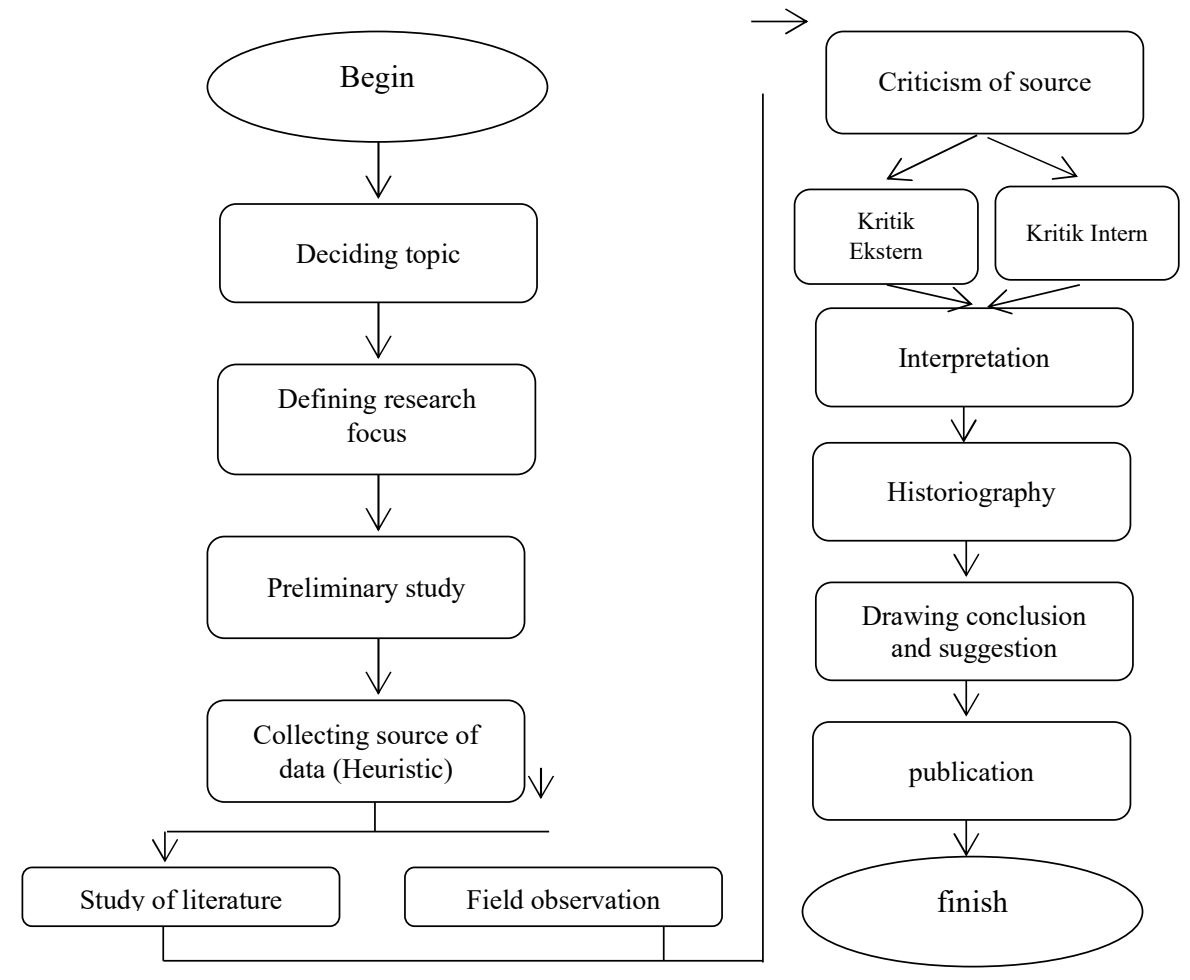

Fig. 1. Research Procedure

\subsection{Source of Data}

The source of data was divided into primary and secondary data. The primary data was the main data that would be used as the main reference. These were: 
1. Document, document concerning the development mapping of TK ABA. The most commonly used were any relevant archives in TK ABA, photograph, and any documents issued by 'Aisyiyah, NA, and Muhammadiyah.

2. Informant. The data that would be obtained from informant was data obtained from interviewing teacher, education staff, public figure around the kindergarten and other parties who well acknowledged about the object of research.

3. Place and event, that was TK ABA in West Papua as the research object.

\subsection{Technique of Collecting Data}

The techniques of collecting data in this qualitative research were:

1. Depth interview

2. Observation

3. Content analysis

\section{Result And Discussion}

The founder of TK ABA 1 Sorong city was Pak Baharudin Zein, one of the Muhammadiyah leaders from Sumatra, Pak La Dena, and Usman Saad from Buton and other Muhammadiyah leaders. At that time, they gave a mandate to manage TK ABA 1 Sorong city Ibu Siti Hadijah. Ibu Siti Hadijah was the first Principal of TK ABA 1 Sorong city.

Muhammadiyah schools were continuously founded. On 22 July 1970, it was founded TK ABA 1 in Jenderal Yos Sudarso Kampung Baru. The founder of TK ABA 1 was Ibu Sopiyah and the first principal was Hadijah.

Previously, TK ABA 1 building was the colonial booty from Netherland to Indonesia. The buildings were shared by temporary government head (KPS) to various parties such as Cendrawasih University, SMKK Sorong, and Muhammadiyah in Sorong. The organizer of the shared booty lands was Hambali Tagada, the temporary government head (KPS) of Sorong. He was the original member of Muhammadiyah in Sorong since Muhammadiyah was established in Sorong. The available facilities were only a simple building of classrooms made of wooden board.

To fulfill the school facilities, the Muhammadiyah administrators initiated to raise funds through Dolog Chief. At that time, the leftover rice from sweeping was collected and been sold to buy tables, chairs, and etc. however, over the time, TK ABA 1 was switched the ownership. Due to the management conflict of TK ABA 1 Sorong without Muhammadiyah involvement, the conflict was directly handled by the local government, which in this case the education board of Sorong city. It was ended by switching over the ownership of TK ABA 1 Sorong became the asset of local government and Muhammadiyah, then, was given a new building by the government in Rufei district

The public response toward TK ABA 1 Sorong was enthusiastic. Thus, TK ABA 1 became one of favorites TK in Sorong city and it was proved that many people both muslim and non muslim sent their children to TK ABA 1 Sorong.

The first subjects (curriculum) were only Aqidah, and Akhlak. It was due to the many female students had not used veil yet. Nevertheless, the non muslim parents still sent their children to that school because its students were friendly and polite. 
At the beginning of its establishment the intracurricular activities were only in the form of conventional learning, while extracurricular activities had not been designed in a coherent manner. The flagship program was the exemplary of its teachers in community life which then could be imitated. Therefore, the community considered the way of TK ABA teachers in socializing was better than other teachers in other TK. Thus, it made the Christian parents wanted to send their children to that school.

The number of teachers who were in leadership from various periods of the principal was not mentioned due to the absence of the stored archives. Moreover, the current teachers and principals did not remember because they were new or young. Meanwhile, according to the results of the direct interview, they stated that the quality of the teacher who taught at TK ABA 1 Sorong City was good quality and they ever had won a role model award for teacher in West Papua. In 1987, one of them had awarded as teacher model held by PP Muhammadiyah.

Quantitatively, the number of students in TK ABA 1 Sorong at the beginning of its establishment was only 7 students, but in its development there was a significant increase. The peak of its enhancement was in $2001-2004$ with the number of students reached more than 130 students. At that time, TK ABA 1 Sorong became favorite schools in Remu area. Then, there were many public and private schools were built in Remu area. This was why, the number of students enrolled in TK ABA 1 Sorong decreases.

\section{Conclusion}

The conclusions of this research were:

1. The founder of TK ABA 1 Sorong city was Pak Baharudin Zein, one of the Muhammadiyah leaders from Sumatra, Pak La Dena, and Usman Saad from Buton and other Muhammadiyah leaders. At that time, they gave a mandate to manage TK ABA 1 Sorong City to Ibu Siti Hadijah and Ibu Siti Hadijah was the first Principal of TK ABA 1 Sorong City.

2. The first students of TK ABA 1 Sorong city when it was first founded were 7 students. However, through its development, the total number of its students was significantly increased up to more than 130 students in 2001-2004. Previously, TK ABA 1 Sorong city was a favorite school in Remu area but starting on 2007, there were many schools founded that caused the decrease number of students enrolled in TK ABA 1 Sorong city.

\section{Reference}

[1] Bafadal, Ibrahim. 2005. Administrasi dan Supervisi Penyelenggaraan Taman Kanak-kanak. Jakarta: Departemen Pendidikan dan Kebudayaan.

[2] Dalilah Candrawati, Siti. 2015. Rubrik Opini Majalah Walida April-Mei 2015. PWA Jawa Timur: Surabaya.

[3] Daliman, A. 2012. Metode Penelitian Sejarah. Yogyakarta: Penerbit Ombak.

[4] Darban, Ahmad Adaby (editor). 2010. 'Aisyiyah dan Sejarah Pergerakan Perempuan Indonesia: Suatu Tinjauan Awal. Yogyakarta: Jurusan Sejarah Fakultas Ilmu Budaya Universitas Gadjah Mada.

[5] Abdurrahman, Dudung. 1999. Metode Penelitian Sejarah. Jakarta: Logos Wacana 
2010. Sejarah Kauman Menguak Identitas Kampung Muhammadiyah. Yogyakarta: Sura Muhammadiyah.

[7] Gottschalk, Louis. 1983. Mengerti Sejarah, terjemahan Nugroho Notosusanto. Jakarta: UI Press.

[8] Hadi, Sutrisno.2002. Metodologi Riset. Yogyakarta: Andi Ofset.

[9] Hapsari, Ratna dan M. Adil. 2013. Sejarah Indonesia Jilid 1 Untuk SMA/MA Kelas X. Jakarta: Erlangga.

[10] Kartodirdjo, Sartono. 1982. Pemikiran dan Perkembangan Historiografi Indonesia Suatu Alternatif,. Jakarta: Gramedia.

[11] .1993. Pendekatan Ilmu Sosial dalam Metodologi Sejarah. Jakarta: Gramedia Pustaka Utama.

[12] Koentjaraningrat, "Metode Wawancara," dalam Koentjaraningrat (ed.). 1994. Metodemetode Penelitian Masyarakat. Jakarta: Gramedia.

[13] Kuntowijoyo. 1995. Pengantar Ilmu Sejarah. Yogyakarta: Bentang Budaya.

[14] Kuntowijoyo. 2003. Metodologi Sejarah. Yogyakarta: CV. Tiara Wacana.

[15] Maarif, Ahmad Syafii. 1987. Islam dan Masalah Kenegaraan Studi tentang Percaturan dalam Konstituante. Jakarta: LP3ES.

[16] Moleong, Lexy J.,2001. Metodologi Penelitian Kualitatif. Bandung: Remaja Rosdakarya.

[17] Mu'arif dan Hajar Nur Setyowati. 2011. Srikandi-srikandi 'Aisyiyah, (Yogyakarta: Suara Muhammadiyah.

[18] Puar, Yusuf Abdullah. 1989. Perjuangan dan Pengabdian Muhammadiyah, (Jakarta: Pustaka Antara.

[19] Putra, Nusa dan Dwilestari, Ninin. 2012. Penelitian Kualitatif PAUD. Jakarta: PT. Raja Grafindo.

[20] Sjamsudin, Helius. 2012. Metodologi Sejarah. Yogyakarta: Ombak.

[21] Storey, William Kelleher. 2011. Menulis Sejarah Panduan untuk Mahasiswa. Alih bahasa Abdillah Halim. Yogyakarta: Pustaka Pelajar.

[22] Sutopo, HB. 2006. Metode Penelitian Kualitatif. Surakarta: UNS Press.

[23] Suwarno, 2014. “'Aisyiyah: Pelopor Gerakan Pemberdayaan Perempuan di Indonesia," dalam Suswandari, dkk. Berbincang tentang Perempuan dan Pendidikan untuk Kesetaraan Gender. Jakarta: Pusat Pelayanan Terpadu Pemberdayaan Perempuan dan Anak [P2TP2A].

[24] Suyadi. 2010. Psikologi Belajar Anak Usia Dini. Yogyakarta : Pedagogia.

[25] Suyanto, Slamet. 2005. Pembelajaran untuk Anak TK. Jakarta: Depdiknas.

[26] Tilaar, H.A.R. 2012. Kalaedoskop Pendidikan Nasional. Jakarta: Kompas.

[27] Tamburaka, Apriyadi. 2012. Agenda Setting Media Massa. Jakarta: PT Raja Grafindo Persada.

[28] Tim Penyusun, 2013. Muhammadiyah 100 Tahun Menyinari Negeri. Yogyakarta: Majelis Pustaka dan Informasi Pimpinan Pusat Muhammadiyah.

[29] Widja, I.G. 1988. Pengantar Ilmu Sejarah, Sejarah dalam Perspektif Pendidikan. Semarang: Satya Wacana. 